WAR AND THE HEALTH OF NATIONS 



\section{WAR AND THE HEALTH}

\section{OF NATIONS}

ZARYAB IQBAL 
Stanford University Press

Stanford, California

() 2010 by the Board of Trustees of the Leland Stanford Junior University. All rights reserved. No part of this book may be reproduced or transmitted in any form or by any means, electronic or mechanical, including photocopying and recording, or in any information storage or retrieval system without the prior written permission of Stanford University Press.

Printed in the United States of America on acid-free, archival-quality paper Library of Congress Cataloging-in-Publication Data

Iqbal, Zaryab.

War and the health of nations / Zaryab Iqbal.

p. $\mathrm{cm}$.

Includes bibliographical references and index.

ISBN 978-0-8047-5881-9 (cloth : alk. paper)

1. War-Health aspects. 2. War-Medical aspects. 3. War and society.

4. Public health. I. Title.

RA646.I67 2010

$362.1-\mathrm{dc} 22 \quad 2009029235$

Typeset by Westchester Book Group in 10/14 Minion 
I dedicate this book to my parents 
